\title{
U.S. Geological Survey Studies Quality of Drinking-Water Supplies in the Mississippi Embayment-Texas Coastal Uplands Principal Aquifer
}

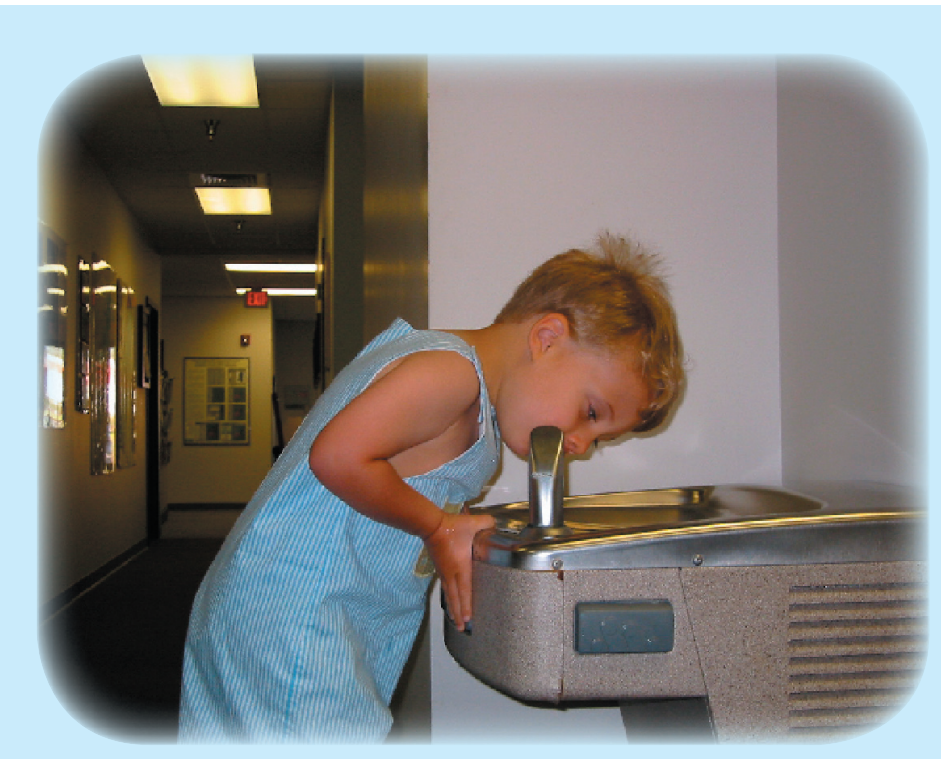

\begin{abstract}
One of the primary missions of the U.S. Geological Survey (USGS) is to evaluate the quantity and quality of the Nation's water resources. To this end, since 1991 the National Water Quality Assessment (NAWQA) Program of the USGS has been collecting data on many of the Nation's principal aquifers used as a source for drinking water, including the Mississippi Embayment-Texas Coastal Uplands (METX) principal aquifer. There have been three separate studies of the aquifer by the NAWQA Program from 1994 until 2004; these studies have been local in nature and covered only small parts of the principal aquifer. In 2005, a synthesis of the results from the three studies was begun to evaluate the quality of water and to understand how it changes throughout the principal aquifer.
\end{abstract}

\section{Introduction}

The quality and quantity of ground water can affect the health and well-being of citizens who depend upon ground water for drinking-water supply, as well as have important consequences to the economic well being of a community. For many Americans, ground water is the primary source of drinking water. It also replenishes our streams and rivers, and provides freshwater for irrigation and industry.

An aquifer is a geologic formation, a group of formations, or part of a formation that contains sufficient saturated permeable material to yield substantial quantities of water to wells and springs. Currently 16 of the Nation's 62 prin-

A principal aquifer is defined as a regionally extensive aquifer or aquifer system that has the potential to be used as a source of potable water. cipal aquifers are being studied by the NAWQA Program. In aggregate, these 16 principal aquifers accounted for about three quarters of the estimated withdrawals for drinking-water supply in 1990 from the Nation's 62 principal aquifers. The METX principal aquifer was ranked 9th (with 1st being the largest use) of the 62 principal aquifers for 1990 estimated drinking-water use.

\section{Mississippi Embayment-Texas Coastal Uplands Regional Aquifer}

The METX principal aquifer has an approximate areal extent of about 197,190 square miles and includes parts of the Cockfield, Sparta, Memphis, and Wilcox aquifers in Alabama, Arkansas, Illinois, Kentucky, Louisiana, Missouri, Mississippi, Tennessee, and Texas. A detailed description of the aquifers and corresponding geohydrologic units can be found in the Ground Water Atlas of the United States (Ryder, 1996; Renken,
Geohydrologic units and corresponding local aquifer names

\begin{tabular}{ll} 
Geohydrologic Unit & $\begin{array}{l}\text { Local aquifer name } \\
\text { (number of wells } \\
\text { sampled) }\end{array}$ \\
\hline $\begin{array}{l}\text { Mississippi River } \\
\text { Valley alluvial } \\
\text { aquifer }\end{array}$ & $\begin{array}{l}\text { Mississippi River } \\
\text { alluvial aquifer } \\
\text { Shallow water- } \\
\text { table aquifer (24) }\end{array}$ \\
Upper Claiborne & Cockfield aquifer (2) \\
aquifer &
\end{tabular}

$\begin{array}{ll}\text { Middle Claiborne } & \text { Memphis-Sparta } \\ \text { aquifer } & \text { aquifer (25) }\end{array}$

Lower Claiborne- Carrizo aquifer (23)

Upper Wilcox

Meridian-upper

aquifer

Wilcox aquifer (2)
Fort Pillow aquifer (1) Wilcox aquifer (8) 


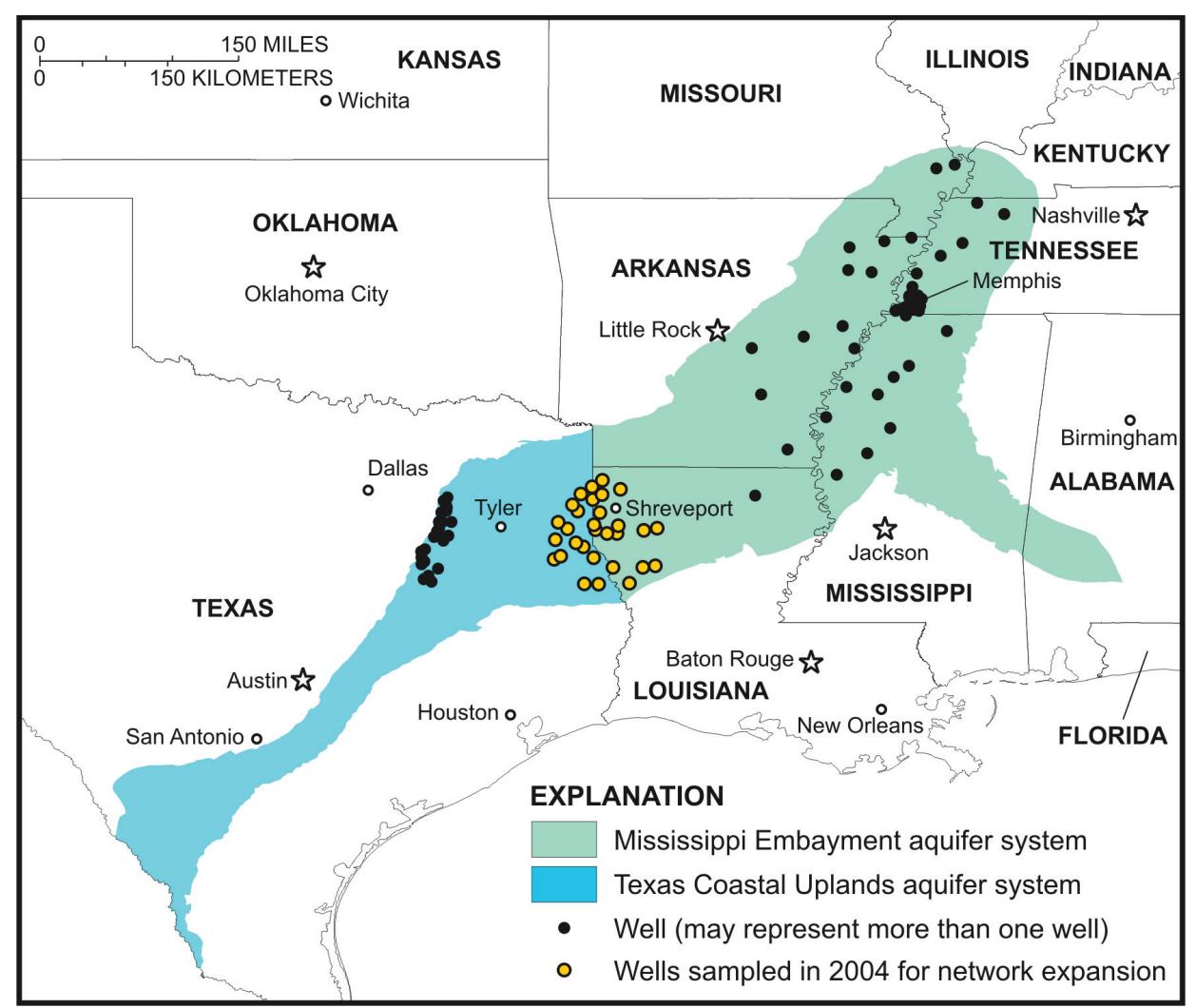

Areal extent of Mississippi Embayment - Texas Coastal Uplands aquifer system and location of wells sampled.

1998). For the purpose of this discussion, aquifers are referred to here using local nomenclature.

\section{Mississippi River Alluvial Aquifer}

\section{Shallow Water Table Aquifer}

Although not part of the METX principal aquifer, there is direct connection between the shallow water-table aquifer and the upper part of the Memphis aquifer in some areas east of Memphis, Tennessee. The potential exists for water and contaminants in this shallow aquifer to move into the lower part of the Memphis aquifer.

The shallow water table aquifer is not used as a primary ground-water resource within the Memphis vicinity. In rural areas near the Memphis metropolitan area, however, some small domestic and livestock wells pump from the shallow water-table aquifer.

\section{Mississippi Embayment Aquifer System}

The Mississippi Embayment aquifer system consists of the aquifers that are in the Claiborne and Wilcox Groups of Tertiary age. Aquifers that were sampled include the Cockfield, Memphis-Sparta, sippi. Along with the Winona-Tallahatta aquifer, the Cane River formation, and the Carrizo aquifer, the Sparta aquifer is considered the equivalent of the Memphis aquifer in Tennessee.

\section{Meridian-Upper Wilcox Aquifer}

The Meridian Sand in Mississippi is situated at the base of the Claiborne Group and is the stratigraphic equivalent to the Carrizo Sand in Arkansas. Thickness of the Meridian-upper Wilcox aquifer is variable and ranges from about 50 to $400 \mathrm{ft}$. Well yields range from 100 to 1,000 gallons per minute ( $\mathrm{gal} / \mathrm{min})$.

\section{Fort Pillow-Wilcox Aquifer}

The Wilcox Group includes at least two major sand units separated by clays that are collectively called the Wilcox aquifer. The Fort Pillow Sand, also named the "1,400-foot " sand in the Memphis area, is included as part of the Wilcox aquifer. The Wilcox aquifer ranges in thickness from 0 to $1,100 \mathrm{ft}$. Well yields range from 500 to 2,000 $\mathrm{gal} / \mathrm{min}$.

\section{Texas Coastal Uplands Aquifer System} Pillow-Wilcox.

\section{Cockfield Aquifer}

The Cockfield aquifer provides water mainly for public and industrial supply (some domestic and livestock wells) in the southern part of the study area in Mississippi and Louisiana. Thickness of the aquifer in the outcrop area ranges from 0 to 700 feet (ft) . Within the study area, the aquifer supplies water to low-yield domestic or stock wells. Just outside the study area in Mississippi, the aquifer is pumped for public supply in some parts of the Jackson metropolitan area.

\section{Memphis-Sparta Aquifer}

Ground water from the lower part of the Memphis aquifer is the primary source of drinking water for the Memphis metropolitan area, including Collierville, Bartlett, Germantown, and Memphis. In 1995, ground-water pumpage was 190 million gallons per day from the lower part of the Memphis aquifer for Shelby County, in the vicinity of Memphis.

The Sparta aquifer is a major drinking water source in southern Arkansas, northern Louisiana, and west-central Missis-

\section{Carrizo-Wilcox Aquifer}

The Carrizo-Wilcox aquifer includes the Carrizo Sand of the Claiborne Group. Municipal and irrigation withdrawals from the aquifer account for about 35 and 51 percent, respectively, of total pumpage. The largest metropolitan areas that are dependent on the aquifer for drinking water are Bryan-College Station, LufkinNacagdoches, and Tyler, Texas (Texas Water Development Board, 2005). The wells in this aquifer were sampled as part of the Carrizo-Wilcox well network.

\section{Data Collection}

Ground-water samples have been collected by NAWQA from parts of the METX principal aquifer since 1994. Sampling throughout the principal aquifer is ongoing, but varies throughout the aquifer in a cyclical manner. Samples have been collected from 85 wells in studies of the Mississippi River alluvial aquifer, the Mississippi Embayment aquifer system, and the Texas Coastal Uplands aquifer system. Data were summarized based on location within the principal aquifer. 


\begin{tabular}{|c|c|c|c|}
\hline What kind of data & Chemical constituents of interest & $\begin{array}{l}\text { Expected in } \\
\text { ground water? }\end{array}$ & $\begin{array}{l}\text { Constituents detected in water sample } \\
\text { (number in parentheses is number of detections) }\end{array}$ \\
\hline Major Ions & $\begin{array}{l}\text { Bicarbonate, bromide, calcium, chloride, } \\
\text { fluoride, iron, magnesium, manganese, po- } \\
\text { tassium, silica, sodium, and total dissolved } \\
\text { solids }\end{array}$ & Yes & $\begin{array}{l}\text { Bicarbonate, sodium, calcium, magnesium, manga- } \\
\text { nese, and iron were the most commonly detected }\end{array}$ \\
\hline Trace elements & $\begin{array}{l}\text { Aluminum, antimony, arsenic, barium, be- } \\
\text { ryllium, cadmium, chromium, cobalt, cop- } \\
\text { per, lead, molybdenum, nickel, selenium, } \\
\text { silver, uranium, and zinc }\end{array}$ & Yes & $\begin{array}{l}\text { Aluminum, barium, chromium, nickel, and zinc } \\
\text { were the most commonly detected. }\end{array}$ \\
\hline Nutrients & $\begin{array}{l}\text { Ammonia, ammonia plus organic nitrogen, } \\
\text { nitrite plus nitrate, nitrite, organic carbon, } \\
\text { orthophosphate, and phosphorus }\end{array}$ & Yes & $\begin{array}{l}\text { Ammonia (40); ammonia plus organic nitrogen } \\
\text { (31); nitrite plus nitrate (46); nitrite (3); organic } \\
\text { carbon (49); orthophosphate (56); and phosphorus } \\
\text { (55) }\end{array}$ \\
\hline Pesticides & $\begin{array}{l}75 \text { pesticides and } 8 \text { pesticide degradates } \\
\text { including atrazine, bromacil, deethyl atra- } \\
\text { zine, diazinon, metolachlor, prometon, and } \\
\text { simazine }\end{array}$ & No & $\begin{array}{l}33 \text { wells had pesticide detections. Atrazine (13); } \\
\text { bromacil (3); deethyl atrazine (10); diazinon (4); } \\
\text { metolachlor (10); prometon (2); and simazine (12) }\end{array}$ \\
\hline $\begin{array}{l}\text { Volatile } \\
\text { organic } \\
\text { compounds } \\
\text { (VOCs) }\end{array}$ & $\begin{array}{l}87 \text { VOCs including carbon disulfide, chlo- } \\
\text { roform, vinyl chloride, benzene, toluene, } \\
\text { ethyl-benzene, m- and p-xylenes, tetra- } \\
\text { choroethen, and methyl tert-butyl ether }\end{array}$ & No & $\begin{array}{l}67 \text { wells had detections. Carbon disulfide ( } 24) \text {; } \\
\text { chloroform (12); m- and p-xylenes (14); tetra- } \\
\text { choroethene (9); and toluene (7) }\end{array}$ \\
\hline
\end{tabular}

\section{Why are these constituents important?}

\section{Major lons}

Major ions affect some basic chemical characteristics of water such as taste, color, and hardness. Calcium and magnesium contribute to hardness of water, which is an indicator of the water's ability to form insoluble residues with soaps and to form scale in plumbing fixtures associated with heating water. High dissolved solids concentrations can affect suitability of water for drinking purposes. High concentrations of iron and manganese can cause discoloration of water.

\section{Trace Elements}

The human body needs iron, copper, manganese, and zinc in trace quantities, but larger amounts of these elements in the body may be toxic. Other elements, such as arsenic and cadmium, are toxic even at trace quantities in the human body. Some of the more toxic trace elements are cumulative, systemic poisons that can be categorized as carcinogens. Chronic exposure to certain trace elements can cause damage to the digestive, respiratory, and nervous systems.

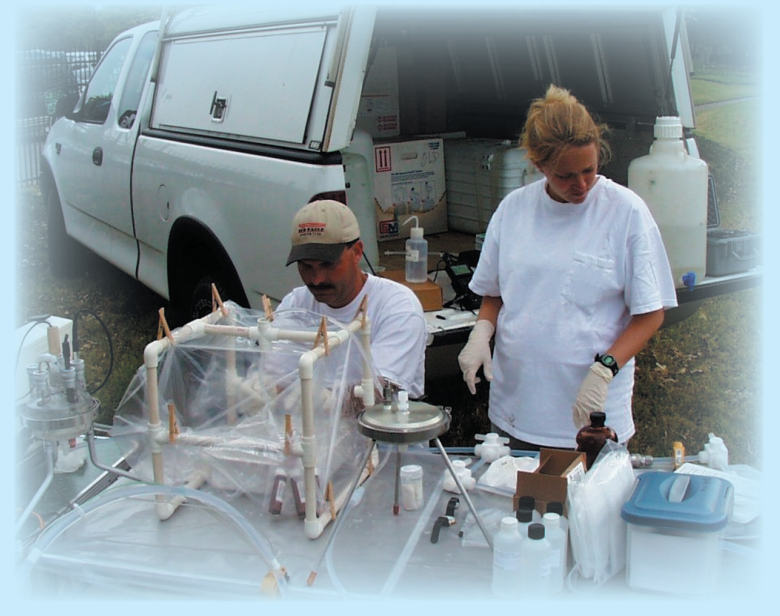

\section{Nutrients}

Excessive nutrients can have adverse effects on human health. Nitrate and phosphorus in water can promote the growth of pathogens that may cause gastrointestinal-related illness. Elevated concentrations of nitrate in drinking water have been associated with methemoglobinemia or "blue-baby" syndrome and with increased rates of stomach cancer.
Elevated nutrients in ground-water discharge can contribute to nuisance algae and aquatic plant growth in streams or lakes.

\section{Pesticides}

Pesticides in water supplies have been of interest since before 1972 when the manufacture and usage of DDT was banned in the United States. Many pesticides used today to control weeds, insects, and fungi that inhibit the growth of crops can threaten human health. Pesticides have varying chemical and physical properties and have a tendency to reside in the soil. Herbicides generally are more soluble than other pesticides and are more likely to infiltrate to the water table.

\section{Volatile Organic Compounds}

Volatile organic compounds (VOCs) are soluble, mobile, and persistent in ground water, and many are suspected carcinogens. Many commonly used substances such as gasoline, refrigerants, paints, and plastics contain VOCs. 


\begin{tabular}{|c|c|c|c|}
\hline Aquifers sampled & $\begin{array}{l}\text { Well depths } \\
\text { (in feet) }\end{array}$ & Sampling period & Significant findings \\
\hline $\begin{array}{l}\text { Mississippi River Valley } \\
\text { alluvial aquifer } \\
\text { Shallow water table } \\
\text { Upper Memphis aquifer }\end{array}$ & 33 to 109 & April -May 1997 & $\begin{array}{l}\text { Atrazine was the only compound in this study detected at a } \\
\text { concentration that exceeded a U.S. Environmental Protection } \\
\text { Agency primary drinking-water standard. }\end{array}$ \\
\hline $\begin{array}{l}\text { Mississippi Embayment aquifer } \\
\text { system } \\
\text { Cockfield aquifer } \\
\text { Memphis-Sparta aquifer } \\
\text { Meridian-upper Wilcox aquifer } \\
\text { Fort Pillow-Wilcox aquifer }\end{array}$ & 208 to 1,460 & April - May 1996 & $\begin{array}{l}\text { Water from } 3 \text { wells had total dissolved solids concentrations } \\
\text { higher than the Secondary Drinking Water Regulation (SDWR; } \\
\text { U.S. Environmental Protection Agency); } 13 \text { wells had iron con- } \\
\text { centrations higher than the SDWR; and } 9 \text { wells had manganese } \\
\text { concentrations higher than the SDWR. }\end{array}$ \\
\hline $\begin{array}{l}\text { Texas Coastal Uplands aquifer } \\
\text { system } \\
\text { Carrizo-Wilcox aquifer }\end{array}$ & 21 to 462 & February - August 1994 & $\begin{array}{l}\text { Concentrations of dissolved solids and iron were higher than } \\
\text { the SDWR established for drinking water by the U.S. Environ- } \\
\text { mental Protection Agency in four wells; manganese concentra- } \\
\text { tions were higher than the SDWR in eight wells. }\end{array}$ \\
\hline
\end{tabular}

\section{Significant Findings}

Although the quality of water from the METX principal aquifer generally is good, there were a few detections of some anthropogenic (non-naturally occurring) compounds such as pesticides and volatile organic compounds (VOCs). The presence of these compounds could indicate degradation of the quality of water in the aquifer and requires further investigation.

In order to better characterize the water quality of the METX principal aquifer, an additional 30 wells were sampled in the Shreveport, Louisiana, area in 2004, and those data will be part of the regional assessment.

\section{Additional Reading}

Much of the material included here has been previously presented in the following publications.

Gonthier, G.J., 2000, Water quality in the deep Tertiary aquifers of the Mississippi Embayment, 1996: U.S. Geological Survey Water-Resources Investigations Report 99-4131, 91 p.

Gonthier, G.J., 2002, Quality of shallow ground water in recently developed residential and commercial area, Memphis vicinity, Tennessee, 1997: U.S. Geological Survey Water-Resources Investigations Report 02-4294, 105 p.
Kleiss, B.A., Coupe, R.H., Gonthier, G.J., and Justus, B.J., 2000, Water quality in the Mississippi Embayment: Mississippi, Louisiana, Arkansas, Missouri, Tennessee, and Kentucky, 1995-98: U.S. Geological Survey Circular 1208, 36 p.

Land, L.F., Moring, J.B., Van Metre, P.C., Reutter, D.C., Mahler, B.J., Shipp, A.A., and Ulery, R.L., 1998, Water quality in the Trinity River Basin: Texas, 1992-95: U.S. Geological Survey Circular 1171, 39 p.

Renken, R.A, 1998, Ground water atlas of the United States-Segment 5, Arkansas, Louisiana, Mississippi: :U.S. Geological Survey Hydrologic Investigations Atlas 730-F, 28 p.

Reutter, D.C., and Dunn, D.D., 2000, Waterquality assessment of the Trinity River Basin, Texas--Ground-water quality of the Trinity, Carrizo-Wilcox, and Gulf Coast aquifers, February-August 1994: U.S. Geological Survey Water-Resources Investigations Report 99-4233, 56 p.

Ryder, P.D., 1996, Ground water atlas of the United States-Segment 4, Oklahoma and Texas: U.S. Geological Survey Hydrologic Atlas 730-E, 30 p.

Texas Water Development Board, 2005, Carrizo-Wilcox aquifer, accessed July 26, 2005, at http://www.twdb.state.tx.us/publications/reports/GroundWaterReports/ GWReports

U.S. Environmental Protection Agency, Understanding the Safe Drinking Water Act, accessed May 10, 2005, at http://www.epa.gov/safewater/sdwa/30th/ factsheets/understand.html

\section{USGS Data are Publicly Available}

The National Water Information System (NWISweb) is the USGS database for water-quality conditions and other information. NWISweb is publicly available and can be readily accessed via the Internet (http://water. usgs.gov/nwis).

\section{Additional Information}

For additional information about the Mississippi Embayment-Texas Coastal Uplands Principal Aquifer NAWQA study contact:

U.S. Geological Survey

Mississippi Water Science

Center

308 South Airport Rd.

Jackson, MS 39208-6649

http://ms.water.ugsg.gov/

U.S. Geological Survey

Texas Water Science Center 8027 Exchange Dr.

Austin, TX 78754-4733

http://tx.water.usgs.gov/

U.S. Geological Survey

Louisiana Water Science Center 3535 S. Sherwood Forest Blvd.,

Suite 120

Baton Rouge, LA 70816

http://la.water.usgs.gov/

Compiled by

Carol P. Moss and Heather L. Welch 